\title{
Emended Descriptions of Prevotella denticola, Prevotella loescheii, Prevotella veroralis, and Prevotella melaninogenica
}

\author{
CHAO-CHUN WU, ${ }^{1}$ J. L. JOHNSON, ${ }^{2}$ W. E. C. MOORE, ${ }^{2 *}$ AND L. V. H. MOORE ${ }^{2}$ \\ Culture Collection and Research Center, Food Industry Research and Development Institute, Hsinchu 30099, \\ Taiwan, Republic of China, ${ }^{1}$ and Department of Anaerobic Microbiology, Virginia Polytechnic \\ Institute and State University, Blacksburg, Virginia 24061-0305
}

\begin{abstract}
During studies of human periodontal disease, a number of bacterial strains were encountered that, on the basis of results of standard biochemical tests, appeared to be Prevotella buccalis, Prevotella denticola, Prevotella melaninogenica, or Prevotella loescheii. However, use of the standard biochemical tests, cellular fatty acid analyses, and the polyacrylamide gel electrophoresis patterns of soluble proteins resulted in conflicting identifications of these strains. The results of tests for cellobiose fermentation, inulin fermentation, and pigment production were responsible for most of the discordant results. Cellular fatty acid analyses in which the Microbial Identification System was used did not differentiate these strains from validly described species, even though separate library entries were created for them. DNA reassociation determinations in which the S1 nuclease procedure was used showed that cellobiose fermentation and pigment production are variable among strains of $P$. melaninogenica and $P$. denticola and that fermentation of xylan is not a reliable characteristic for differentiating $\boldsymbol{P}$. buccalis from Prevotella veroralis. In contrast to previous indications, most strains of $\boldsymbol{P}$. veroralis do not ferment xylan. These species can be differentiated by DNA-DNA reassociation and by cellular fatty acid analysis, using the Microbial Identification System, but differentiation by currently described phenotypic characteristics is not reliable. Similarly, $P$. loescheii and the genetically distinct (but closely related) D1C-20 group cannot be distinguished reliably from each other or from $P$. veroralis, $P$. denticola, and $P$. melaninogenica on the basis of currently described phenotypic tests other than cellular fatty acid composition or, for some species, electrophoretic patterns of soluble whole-cell proteins.
\end{abstract}

Prevotella species are a major portion of the microflora of human gingival crevices in patients with periodontal disease (9). The similarity of the phenotypic characteristics of these species often makes their routine differentiation and identification difficult. A total of 19 strains of phenotypically similar Prevotella (Bacteroides) species were used in this study in an attempt to determine their DNA relatedness and to identify reliable phenotypic characteristics for their differentiation. As a result of these analyses, we propose emended descriptions of Prevotella veroralis, Prevotella denticola, Prevotella melaninogenica (2381 DNA-DNA similarity group that contains the type strain), Prevotella loescheii, and the genetically closely related D1C-20 group (3).

\section{MATERIALS AND METHODS}

The strains used in this study are shown in Table 1. Most of these strains were isolated from human gingival or subgingival plaque; the exceptions were $P$. loescheii VPI 9621 , which came from a human cranial abscess, and $P$. melaninogenica VPI 15087, which came from sputum. Strain VPI D1C-20B was a recent single-colony isolate obtained from the original lyophilized culture of strain D1C-20, and strain VPI 15056 was strain D1C-20 accessioned under a different Virginia Polytechnic Institute and State University (VPI) number. Strains belonging to named species had characteristics that have been described previously $(3,4,7,16)$. Strains of phenospecies "Prevotella D70" were similar to Prevotella buccalis phenotypically but produced discordant cellular fatty acid and polyacrylamide gel electrophoresis profiles. Three nonpigmenting strains of phenospecies "Prevotella D71" were identified as $P$. denticola by cellular fatty

\footnotetext{
* Corresponding author.
}

acid analysis but were unlike $P$. denticola in that cellobiose was fermented. Two pigmenting strains that had characteristics of $\boldsymbol{P}$. loescheii (acid production from cellobiose and pigmenting) also were included in phenospecies "Prevotella D71" because of their different cellular fatty acid profiles. Isolates VPI D136E-13a, VPI D136E-13b, and VPI D136E13c were different single colonies that were picked from strain VPI D136E-13 in an effort to purify the culture, which was thought to be a mixture of $P$. loescheii and $P$. melaninogenica.

All of the strains listed in Table 1 were characterized phenotypically on at least two occasions, at the time of original isolation or receipt in our laboratory and from lyophilized cultures when this study was initiated, which was 5 to 13 years later.

The methods used for cultural tests and the conditions used were those described by Holdeman et al. (2); the tests included tube tests in prereduced media and analysis of short-chain fermentation acids by gas-liquid chromatography. The methods used for electrophoretic analysis of soluble cellular proteins were the methods described by Moore et al. (8), and the methods used for cellular fatty acid analysis were the methods described by Sasser (13). For some strains, $10 \%$ (vol/vol) sterile rabbit serum was added to differential media to enhance growth. Final $\mathrm{pH}$ values of cultures in fermentation broth media containing glucose, glycogen, maltose, starch, or trehalose also were determined without added serum to verify the fermentation of these substrates in the absence of serum amylase (3). Pigmentation of colonies was determined by examining growth on supplemented brain heart infusion agar (2) or Trypticase soy-yeast extract agar, both containing 5\% (vol/vol) hemolyzed rabbit blood, following anaerobic incubation for at least 14 days. The susceptibilities of the strains to $12 \mu \mathrm{g}$ of chloramphenicol per $\mathrm{ml}, 1.6 \mu \mathrm{g}$ of clindamycin per $\mathrm{ml}, 3 \mu \mathrm{g}$ of erythro- 


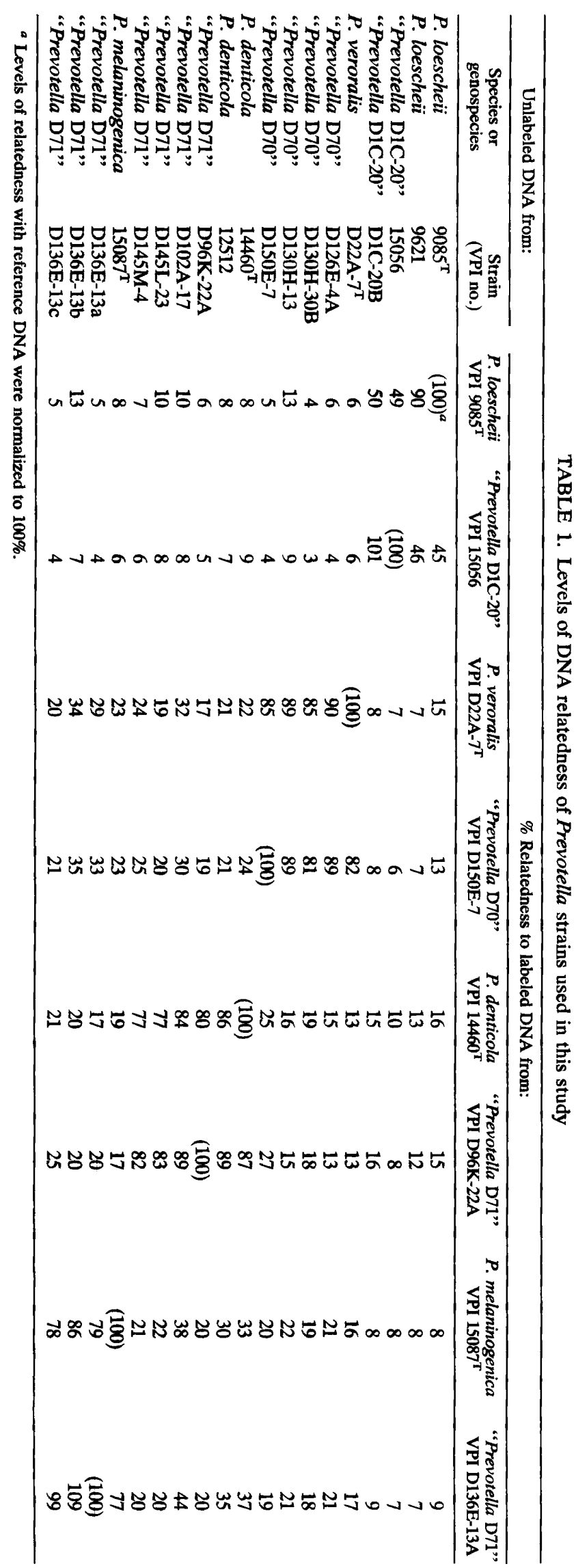

mycin per $\mathrm{ml}, 2 \mathrm{U}$ of penicillin $\mathrm{G}$ per $\mathrm{ml}$, and $6 \mu \mathrm{g}$ of tetracycline per $\mathrm{ml}$ were tested by using the broth disk method of Wilkins and Thiel (18).

For DNA preparations cultures were grown in the BHIPYG medium of Holdeman and Johnson (3), which contained mineral salts $(2 \mathrm{ppm}$ of calcium chloride, $2 \mathrm{ppm}$ of magnesium sulfate, $20 \mathrm{ppm}$ of sodium chloride), $1 \%$ (wt/vol) pepticase, $0.5 \%$ (wt/vol) yeast extract, $1 \%$ (wt/vol) dehydrated brain heart infusion broth (Difco Laboratories, Detroit, Mich.), $0.05 \%$ (wt/vol) hemin, and $0.05 \mathrm{M}$ potassium phosphate buffer. The medium was prepared in $300-\mathrm{ml}$ quantities in 1-liter Erlenmeyer flasks as described by Cummins and Johnson (1). A 3-ml portion of $10 \%(\mathrm{wt} / \mathrm{vol})$ sterile aqueous $\mathrm{NaHCO}_{3}$ was added to each $300 \mathrm{ml}$ of medium. The flasks were inoculated with $15-\mathrm{ml}$ portions of 18 -h cultures grown in chopped meat broth medium and were incubated at $37^{\circ} \mathrm{C}$ for 18 to $24 \mathrm{~h}$.

DNA was isolated by using a variation of the procedure described by Saghai-Maroof et al. (12). Cells were harvested by centrifugation at $8,200 \times g$ for 10 to $15 \mathrm{~min}$ and were resuspended in suspension buffer $(10 \mathrm{mM}$ Tris- $\mathrm{HCl}$ [pH 8.0], $1 \mathrm{mM}$ EDTA [pH 8], $0.35 \mathrm{M}$ sucrose). Lysozyme ( $2 \mathrm{mg} / \mathrm{ml})$ was added, and the resulting suspension was incubated at $37^{\circ} \mathrm{C}$ until lysis was complete. The solution was mixed with an equal volume of $2 \times$ lysing solution $(90 \mathrm{mM}$ Tris- $\mathrm{HCl}[\mathrm{pH}$ 8.0 ], $1.5 \mathrm{M} \mathrm{NaCl}, 20 \mathrm{mM}$ EDTA, 2\% CTAB, $2 \%$ [vol/vol] 2-mercaptoethanol, $200 \mu \mathrm{g}$ of proteinase $\mathrm{K}$ per $\mathrm{ml}$ ) and then incubated for about $4 \mathrm{~h}$ at $60^{\circ} \mathrm{C}$. The lysate was extracted with chloroform-isopentanol until there was little or no protein at the interface. Then 0.6 volume of isopropanol was added to precipitate the DNA. The DNA was washed twice with a $76 \%$ aqueous ethanol-10 $\mathrm{mM}$ ammonium acetate mixture. The DNA clot was air dried in a $37^{\circ} \mathrm{C}$ incubator and was dissolved in $20 \mathrm{ml}$ of TE buffer ( $10 \mathrm{mM}$ Tris- $\mathrm{HCl}, 1 \mathrm{mM}$ EDTA [pH 8.0]). RNase A (1.0 ml of a $0.5-\mathrm{mg} / \mathrm{ml}$ solution) and phage RNase $T_{1}(5 \mu l$ of a $200-\mathrm{U} / \mathrm{ml}$ solution) were added, and the solution was incubated for $1 \mathrm{~h}$ and then extracted once with chloroform-isoamyl alcohol (25:1). A $0.1 \%$ volume of $3 \mathrm{M}$ sodium acetate was added, and the preparation was overlaid with 2 volumes of $95 \%$ ethanol. The precipitated DNA was spooled onto a glass rod. The DNA was washed with $76 \%$ ethanol in water at $20^{\circ} \mathrm{C}$ and air dried. Finally, the DNA was dissolved in 3 to $5 \mathrm{ml}$ of TE buffer and stored at $-20^{\circ} \mathrm{C}$.

The concentration of the DNA was determined by measuring $A_{260}(5,10,17)$. The purity of each preparation was determined by measuring the hyperchromic shift during thermal denaturation (5). Each DNA preparation was adjusted to a concentration of $0.4 \mathrm{mg} / \mathrm{ml}$ with TE buffer.

The DNA preparations were sheared by passing each of them three times through a French pressure cell at 16,000 $\mathrm{lb} / \mathrm{in}^{2}$, were denatured by heating them in a boiling water bath for $5 \mathrm{~min}$, and then were cooled quickly by placing the tubes in ice water (6). The DNA preparations were then centrifuged at $12,000 \times g$ for $15 \mathrm{~min}$ to remove particulate debris and were stored at $-20^{\circ} \mathrm{C}$. Small amounts $(5 \mu \mathrm{g})$ from the fragmented and denatured DNA preparations were labeled with ${ }^{125} \mathrm{I}$ as described by Selin et al. (14).

The S1 nuclease procedure was used for the DNA similarity determinations $(5,6)$. Each of the reassociation vials contained $10 \mu \mathrm{l}$ (10 to $20 \mathrm{ng} ; 30,000 \mathrm{cpm}$ ) of labeled DNA, 50 $\mu \mathrm{l}(20 \mu \mathrm{g})$ of unlabeled DNA, and $50 \mu \mathrm{l}$ of $13.2 \times \operatorname{SSC}(1 \times$ SSC is $0.15 \mathrm{M} \mathrm{NaCl}$ and $15 \mathrm{mM}$ sodium citrate, $\mathrm{pH} 7.0$ ) containing $5 \mathrm{mM}$ HEPES $\left(N\right.$-2-hydroxyethylpiperazine- $N^{\prime}$ 2-ethanesulfonic acid) buffer ( $\mathrm{pH} 7.0)$. These vials were incubated at $65^{\circ} \mathrm{C}$ for $24 \mathrm{~h}$. Labeled reference DNA prepa- 
TABLE 2. Cellular fatty acid compositions of $P$. denticola, $P$. loescheii, genospecies "Prevotella D1C-20," $P$. melaninogenica, and $P$. veroralis

\begin{tabular}{|c|c|c|c|c|c|}
\hline \multirow{2}{*}{ Compound ${ }^{a}$} & \multicolumn{5}{|c|}{ Cellular fatty acid composition ${ }^{b}$} \\
\hline & P. loescheii & "Prevotella D1C-20" & P. denticola & P. melaninogenica & $P$. veroralis \\
\hline 13:0 iso FAME & & & $0.8 \pm 0.2$ & $0.8 \pm 0.4$ & $1.0 \pm 0.3$ \\
\hline 13:0 anteiso FAME & & & & & $0.4 \pm 0.2$ \\
\hline $14: 0$ iso FAME & $6.7 \pm 2.4$ & $7.1 \pm 1.8$ & $6.9 \pm 3.4$ & $5.4 \pm 2.2$ & $6.1 \pm 3.8$ \\
\hline 14:0 FAME & $9.1 \pm 3.6$ & $8.8 \pm 3.7$ & $1.1 \pm 0.4$ & $1.5 \pm 1.0$ & $0.9 \pm 0.4$ \\
\hline 15:0 iso FAME & $11.1 \pm 2.5$ & $10.1 \pm 1.3$ & $7.4 \pm 1.5$ & $8.2 \pm 1.9$ & $10.7 \pm 2.7$ \\
\hline 15:0 anteiso FAME & $22.3 \pm 5.3$ & $21.6 \pm 3.5$ & $42.3 \pm 4.2$ & $42.8 \pm 6.3$ & $37.4 \pm 3.3$ \\
\hline 15:0 FAME & $0.5 \pm 0.4$ & & $0.3 \pm 0.2$ & $0.4 \pm 0.2$ & \\
\hline $16: 0$ iso FAME & $1.9 \pm 0.9$ & $2.2 \pm 0.8$ & $3.8 \pm 0.9$ & $3.4 \pm 0.8$ & $4.0 \pm 0.9$ \\
\hline 16:1 cis-9 FAME & $0.7 \pm 0.8$ & $1.1 \pm 1.4$ & & & \\
\hline 16:0 FAME & $24.0 \pm 4.6$ & $29.4 \pm 3.3$ & $9.9 \pm 2.8$ & $7.8 \pm 3.0$ & $5.9 \pm 2.2$ \\
\hline $17: 0$ iso FAME & & & $2.3 \pm 0.7$ & $1.8 \pm 1.1$ & $4.4 \pm 1.6$ \\
\hline 17:0 anteiso FAME & & & $3.7 \pm 0.9$ & $4.3 \pm 2.0$ & $4.6 \pm 1.7$ \\
\hline 16:0 3OH FAME & $11.8 \pm 3.5$ & $11.2 \pm 2.3$ & $6.5 \pm 2.2$ & $5.3 \pm 1.6$ & $3.5 \pm 1.8$ \\
\hline 18:1 cis-9 FAME & $1.3 \pm 0.9$ & $1.2 \pm 0.6$ & & & \\
\hline $17: 0$ ante $3 \mathrm{OH}$ FAME & & & $1.2 \pm 0.6$ & $1.8 \pm 0.9$ & $0.7 \pm 0.6$ \\
\hline $\begin{array}{l}\text { 13:1 cis-12 FAME, } 14: 0 \text { alde, or } 11: 1 \\
\text { 2OH FAME }\end{array}$ & $2.2 \pm 1.5$ & $1.7 \pm 1.4$ & $1.4 \pm 1.4$ & $1.3 \pm 0.8$ & $0.9 \pm 0.7$ \\
\hline $15: 0$ iso alde or un $13.570 \mathrm{ECL}$ & $1.2 \pm 1.3$ & & $3.3 \pm 4.1$ & $5.4 \pm 3.4$ & $9.2 \pm 5.1$ \\
\hline 16:0 iso $30 \mathrm{H}$ FAME or un 17.157 DMA & $0.8 \pm 0.6$ & $0.7 \pm 0.6$ & $1.1 \pm 0.4$ & $1.2 \pm 0.5$ & $0.6 \pm 0.3$ \\
\hline $17: 0$ iso $3 \mathrm{OH}$ FAME or $18: 2$ DMA & $4.7 \pm 2.0$ & $3.4 \pm 1.4$ & $6.7 \pm 2.6$ & $7.5 \pm 2.7$ & $8.8 \pm 3.1$ \\
\hline
\end{tabular}

${ }^{a}$ FAME, fatty acid methyl ester; 3OH, 3-hydroxy; 2OH, 2-hydroxy; alde, aldehyde; un, unknown; ECL, equivalent chain length; DMA, dimethylaldehyde. Compounds that occurred in less than one-half of the isolates of species are not shown and were not used in reference patterns for identification.

${ }^{b}$ Mean percentage of the total sample area \pm standard deviation.

rations reassociated in the presence of $20 \mu \mathrm{g}$ of salmon sperm DNA resulted in background values which were 5 to $10 \%$ of the values obtained when the preparations were reassociated in the presence of unlabeled reference DNA.

\section{RESULTS}

The levels of DNA-DNA relatedness of the strains are shown in Table 1. Strains belonging to $P$. loescheii and the D1C-20 group were closely related, as reported previously (3), and were distinct from the other taxa tested. All four representative strains of "Prevotella D70" exhibited high levels of DNA relatedness to $P$. veroralis. Four of the five strains of "Prevotella D71" tested, which fermented cellobiose, exhibited high levels of relatedness to $P$. denticola, and one strain of "Prevotella D71," represented by three single colonies from the same preparation, was highly related to the type strain of $P$. melaninogenica.

The results of replicate phenotypic testing were similar to the original results. The strains of "Prevotella D71" all fermented cellobiose with different lots of cellobiose substrate, and the results of xylan fermentation were the same for replicate analyses of the same strains. Thus, cellobiose was fermented by some strains of $P$. denticola, as well as by some strains of $P$. melaninogenica, and xylan was or was not fermented by strains of $P$. veroralis.

When it became evident that cellobiose and xylan fermentations were not reliable characteristics for differentiating $P$. veroralis, $P$. melaninogenica, and $P$. denticola, we included the cellobiose-fermenting strains together with other strains in each DNA similarity group to restructure the Microbial Identification System cellular fatty acid reference patterns (Table 2) and used the new reference library to assign other "Prevotella D70" and "Prevotella D71" strains to the three previously described species $(P$. melaninogenica, $P$. denticola, and $P$. loescheii). All of the strains were then used to determine the phenotypic characteristics of these species, as shown in Tables 3 and 4 . In addition to the characteristics shown in Table 3, 70\% of the 30 strains of $P$. veroralis tested did not ferment xylan, $20 \%$ fermented xylan only weakly, and $10 \%$ (the type strain and two other strains) produced strong acid $(\mathrm{pH}<5.5)$.

\section{DISCUSSION}

In previous work the phenotypic characteristics used to differentiate new isolates of $P$. loescheii, $P$. denticola, $P$. melaninogenica, $P$. veroralis, and the $\mathrm{D} 1 \mathrm{C}-20$ genospecies were based on reactions of strains that represented distinct DNA-DNA relatedness groups $(3,4,7,15,16)$. However, only a limited number of such strains was available ( 9 strains of $P$. loescheii [3], 6 strains of the D1C-20 genospecies [3], 12 strains of $P$. melaninogenica [3], 1 strain of $P$. veroralis [16], and 20 strains of $P$. denticola $[3,15])$. On the basis of the results obtained with these few strains, cellobiose fermentation and pigment production were thought to be key tests for differentiation as follows: acid production from cellobiose and pigment production, $P$. loescheii and the genospecies D1C-20; acid production from cellobiose and no pigment production, $P$. veroralis; no acid production from cellobiose and pigment production, $P$. melaninogenica; and no acid production from cellobiose and generally no pigment production, $\boldsymbol{P}$. denticola. Although Holdeman and Johnson (3) reported cellobiose fermentation by $9 \%$ of 12 strains of $P$. melaninogenica that exhibited high levels of DNA relatedness, these authors did not detect cellobiose fermentation by any of 18 strains of $\boldsymbol{P}$. denticola that exhibited high levels of DNA relatedness. Fermentation of xylan by $P$. veroralis was used to separate $P$. veroralis from $P$. denticola, $P$. buccalis, and $P$. oralis (16).

Phenospecies "Prevotella D70" was established in our laboratory to accommodate xylan-negative strains that corresponded to Prevotella buccalis on the basis of fermentation results but appeared to be $P$. veroralis on the basis of the 
TABLE 3. Biochemical characteristics of $P$. denticola, $P$. loescheii, genospecies "Prevotella D1C-20," $P$. melaninogenica, and $P$. veroralis ${ }^{a}$

\begin{tabular}{|c|c|c|c|c|c|}
\hline \multirow[b]{2}{*}{ Characteristic } & \multicolumn{5}{|c|}{$\%$ of isolates that are positive } \\
\hline & $\begin{array}{l}\text { P. denticola } \\
(95 / 60)^{b}\end{array}$ & $\begin{array}{l}\text { P. loescheii } \\
(133 / 68)\end{array}$ & $\begin{array}{c}\text { "Prevotella D1C-20" } \\
(16 / 13)\end{array}$ & $\begin{array}{c}\text { P. melaninogenica } \\
(68 / 51)\end{array}$ & $\begin{array}{l}P . \text { veroralis } \\
(30 / 17)\end{array}$ \\
\hline \multicolumn{6}{|l|}{ Acid produced from: } \\
\hline Amygdalin & 8 & 14 & 0 & 2 & 1 \\
\hline Cellobiose & 22 & 98 & 94 & 15 & 80 \\
\hline Esculin & 57 & 40 & 50 & 15 & 23 \\
\hline D-Fructose & 99 & 92 & 100 & 91 & 97 \\
\hline Gum arabic & 9 & 6 & 0 & 0 & 0 \\
\hline Inulin & 92 & 93 & 100 & 73 & 96 \\
\hline Larch arabinogalactan & 0 & 5 & 6 & 11 & 17 \\
\hline D-(+)-Maltose & 100 & 100 & 100 & 94 & 100 \\
\hline D-Mannitol & 0 & 0 & 0 & 4 & 0 \\
\hline D-(+)-Mannose & 100 & 99 & 100 & 99 & 100 \\
\hline Melezitose & 2 & 0 & 0 & 1 & 0 \\
\hline Melibiose & 14 & 71 & 56 & 3 & 7 \\
\hline Pectin & 16 & 33 & 12 & 16 & 10 \\
\hline D-(+)-Raffinose & 98 & 99 & 100 & 96 & 100 \\
\hline Rhamnose & 1 & 16 & 6 & 1 & 0 \\
\hline D-Ribose & 41 & 4 & 0 & 29 & 0 \\
\hline Salicin & 16 & 37 & 31 & 3 & 7 \\
\hline Starch & 99 & 95 & 100 & 96 & 100 \\
\hline Trehalose & 2 & 16 & 25 & 0 & 0 \\
\hline Xylan & 20 & 14 & 44 & 18 & 33 \\
\hline D-Xylose & 0 & 4 & 3 & 4 & 6 \\
\hline \multicolumn{6}{|l|}{ Hydrolysis of: } \\
\hline Esculin & 96 & 98 & 100 & 84 & 100 \\
\hline Starch & 89 & 89 & 88 & 96 & 83 \\
\hline \multicolumn{6}{|l|}{ Digestion of: } \\
\hline Gelatin & 98 & 98 & 100 & 93 & 73 \\
\hline Milk & 5 & 12 & 19 & 6 & 7 \\
\hline Meat & 15 & 6 & 0 & 6 & 0 \\
\hline Milk curd & 100 & 100 & 100 & 97 & 100 \\
\hline \multicolumn{6}{|l|}{ Production of: } \\
\hline$\beta$-Hemolysis & 5 & 29 & 69 & 12 & 1 \\
\hline Lipase & 0 & 62 & 67 & 0 & 0 \\
\hline
\end{tabular}

a All strains ferment glucose, glycogen, lactose, and sucrose; are inhibited by $20 \%$ bile; and produce little or no hydrogen or other gas. No strain ferments L-arabinose, DL-erythritol, inositol, or L-sorbose; produces indole, catalase, or lecithinase; reduces nitrate; or is motile.

${ }^{b}$ Number of isolates studied/number of people from whom the isolates were obtained.

results of cellular fatty acid analyses. "Prevotella D71" resembled nonpigmenting or weakly pigmenting strains of $P$. loescheii or strains of $P$. denticola or $P$. melaninogenica that produced acid from cellobiose. On the basis of the properties of strains that exhibited high levels of DNA relatedness in this study, greater variation in cellobiose fermentation occurs among strains of $\boldsymbol{P}$. denticola and $\boldsymbol{P}$. melaninogenica than we thought previously and, unlike the type strain, most strains of $P$. veroralis do not ferment xylan. Thus, previous identification keys and charts of reactions are not adequate to differentiate these species because the key characteristics were selected on the basis of too few strains with known DNA relatedness.

Because $P$. veroralis descriptions were based on only one strain characterized by DNA sequence similarity, it was not surprising to find that there was more phenotypic variation than has been reported previously for the species and that other genetically similar strains did not ferment xylan, which unfortunately has been used as a key differential characteristic. Conversely, the description of $P$. denticola was based on 20 strains grouped by DNA similarity, and none of these strains was reported to ferment cellobiose $(3,15)$. Lack of cellobiose fermentation was considered to be a reliable characteristic for the species because so many strains had been included in the study. This assumption, too, was erroneous.

Initially, we did not know whether to rely more upon differentiation by standard phenotypic tests or upon the cellular fatty acid identifications, which also had been developed by analyzing strains belonging to DNA similarity groups. Because the cellular fatty acid analytical procedure was new and the reliability of the identification library entries had not been proved, we followed the usual custom of considering the identifications based on cellular fatty acid analyses wrong and the identifications determined by our standard procedures correct when there was disagreement. However, the results of our DNA reassociation experiments confirmed that the Microbial Identification System identifications were correct, even though they did not agree with standard and accepted identification criteria. Thus, the following two principles were illustrated: (i) It is essential to have many strains of known DNA relatedness in order to select appropriate diagnostic and differential tests; and (ii) when strains that have not been analyzed by using DNA reassociation experiments are used to evaluate new differential tests, the identifications based on the new test(s) may very well be more nearly correct than identifications based on results obtained with the bench mark standard tests. 
TABLE 4. Other characteristics of $P$. denticola, $P$. loescheii, genospecies “Prevotella D1C-20," $P$. melaninogenica, and $P$. veroralis

\begin{tabular}{|c|c|c|c|c|c|}
\hline Characteristic & $\begin{array}{l}\text { P. loescheii } \\
(133 / 68)^{a}\end{array}$ & $\begin{array}{c}\text { "Prevotella D1C-20" } \\
(16 / 13)\end{array}$ & $\begin{array}{l}\text { P. denticola } \\
(95 / 60)\end{array}$ & $\begin{array}{l}P . \text { melaninogenica } \\
(68 / 51)\end{array}$ & $\begin{array}{l}P \text {. veroralis } \\
(30 / 17)\end{array}$ \\
\hline \multicolumn{6}{|c|}{$\%$ of strains with colonies that are ${ }^{b}$ : } \\
\hline Black & 11 & 0 & 4 & 29 & 0 \\
\hline Reddish brown & 48 & 43 & 44 & 47 & 3 \\
\hline Tan & 18 & 38 & 20 & 9 & 27 \\
\hline Colorless & 23 & 19 & 30 & 15 & 70 \\
\hline \multicolumn{6}{|c|}{$\begin{array}{l}\text { Acid products (mean meq } / 100 \mathrm{ml} \pm \\
\text { SEM) }\end{array}$} \\
\hline Acetic acid & $0.97 \pm 0.04$ & $0.95 \pm 0.12$ & $1.75 \pm 0.07$ & $1.41 \pm 0.08$ & $1.52 \pm 0.11$ \\
\hline Formic acid & $\operatorname{Tr}$ & $\operatorname{Tr}$ & $\operatorname{Tr}$ & $\operatorname{Tr}$ & $\mathrm{Tr}$ \\
\hline Isovaleric acid & 0 & 0 & $0.03 \pm 0.005$ & $0.04 \pm 0.005$ & $0.02 \pm 0.003$ \\
\hline Lactic acid & $0.29 \pm 0.04$ & $0.22 \pm 0.04$ & $0.18 \pm 0.02$ & $0.08 \pm 0.01$ & $0.08 \pm 0.02$ \\
\hline Succinic acid & $2.79 \pm 0.14$ & $2.56 \pm 0.32$ & $5.36 \pm 0.30$ & $4.52 \pm 0.30$ & $4.75 \pm 0.31$ \\
\hline \multicolumn{6}{|l|}{$\%$ of strains resistant to: } \\
\hline Chloramphenicol $(12 \mu \mathrm{g} / \mathrm{ml})$ & 2 & 0 & 0 & 0 & 0 \\
\hline Clindamycin $(1.6 \mu \mathrm{g} / \mathrm{ml})$ & 2 & 0 & 1 & 6 & 4 \\
\hline Erythromycin $(3 \mu \mathrm{g} / \mathrm{ml})$ & 15 & 0 & 1 & 9 & 7 \\
\hline Penicillin G $(2 \mathrm{U} / \mathrm{ml})$ & 21 & 12 & 39 & 41 & 7 \\
\hline Tetracycline $(6 \mu \mathrm{g} / \mathrm{ml})$ & 28 & 6 & 8 & 9 & 4 \\
\hline \multicolumn{6}{|c|}{ Sources of strains used in this study } \\
\hline Gingival crevices & + & + & + & + & + \\
\hline Other oral or pleural sites & & & + & + & \\
\hline Other body sites & & & $t^{c}$ & $+^{d}$ & \\
\hline
\end{tabular}

${ }^{a}$ Number of isolates studied/number of people from whom the isolates were obtained.

${ }^{b}$ Pigmentation generally increases as length of incubation increases, is detected more often and more rapidly on hemolyzed blood than on whole blood, and is produced more reliably on rabbit or human blood than on blood from other animal species, including sheep and horses. Nevertheless, some strains of $P$. melaninogenica, $P$. denticola, and $P$. loescheii produce black colonies in $48 \mathrm{~h}$, whereas other strains do not produce pigmented colonies even after 14 to 21 days of incubation on agar containing hemolyzed rabbit blood. Pigmentation may be detected after initial isolation from mixed cultures but not subsequently in pure cultures.

c Spinal fluid.

${ }^{d}$ Abdominal abscess, Whipple's disease, and cystic acnes.

When cellobiose-fermenting strains are included in the phenotypic data base, $P$. veroralis, $P$. denticola, and $P$. melaninogenica cannot be differentiated with certainty by the phenotypic tests that were given in the initial descriptions of these species and that we have used previously (2). In the absence of cellular fatty acid information, only very tentative identifications can be made on the basis of a combination of colony pigmentation; cellobiose, esculin, inulin, and ribose fermentation; and meat digestion.

The cellular fatty acid patterns of $P$. loescheii and of the D1C-20 genospecies are quite distinct from those of the other three species, particularly in the smaller relative amounts of 15:0 anteiso fatty acid methyl ester and greater relative amounts of 16:0 fatty acid methyl ester (Table 2). The similarity between $P$. loescheii and the genospecies D1C-20 is not surprising since these species exhibit moderate levels of DNA relatedness (Table 1). The cellular fatty acid patterns of $P$. denticola, $P$. melaninogenica, and $P$. veroralis are similar to each other, and these three species also exhibit measurable low levels of DNA relatedness to each other (Table 1). However, the Microbial Identification System can differentiate among these species, despite the similarity of the cellular fatty acid patterns.

Table 5 shows the incidence of the species discussed above among isolates taken from the gingival crevices of people with healthy or diseased gingiva. For these determinations 30 colonies were picked in a randomized manner to obtain a representative cross section of the composition of the flora in each sample taken from the depths of the gingival pockets. On the basis of the association of these species with the different disease states, it appears that, of the species considered in this paper, only $P$. denticola may have a significant relationship with periodontal health. The incidence of this species increased directly with the severity of disease. However, it is impossible to tell whether this increase represents a contributing cause of tissue destruction or whether it simply represents growth stimulation by increased serum and blood in affected sites.

TABLE 5. Incidence of $P$. loescheii, "Prevotella D1C-20," $P$. denticola, $P$. melaninogenica, and $P$. veroralis in the gingival crevices of subjects with different levels of periodontal health

\begin{tabular}{|c|c|c|c|c|c|c|c|}
\hline \multirow[b]{2}{*}{ Subjects with: } & \multirow{2}{*}{$\begin{array}{l}\text { No. of } \\
\text { people }\end{array}$} & \multirow{2}{*}{$\begin{array}{l}\text { No. of } \\
\text { isolates }\end{array}$} & \multicolumn{5}{|c|}{$\%$ of total isolates } \\
\hline & & & P. loescheii & $\begin{array}{l}\text { "Prevotella } \\
\text { D1C-20" }\end{array}$ & P. denticola & P. melaninogenica & P. veroralis \\
\hline Healthy gingiva & 20 & 1,047 & 0.29 & 0 & 0.29 & 0.10 & 0 \\
\hline Adult gingivitis & 11 & 680 & 0.59 & 0.44 & 0.74 & 0.29 & 0 \\
\hline Adult periodontitis & 25 & 1,913 & 0.47 & 0.47 & 0.89 & 0.26 & 0.05 \\
\hline Severe periodontitis & 21 & 1,315 & 0.30 & 0.38 & 1.98 & 0 & 0 \\
\hline
\end{tabular}




\section{ACKNOWLEDGMENTS}

We gratefully acknowledge the technical assistance of Ann Ridpath, Jane Hungate, Pauletta Atkins, Ann Donnelly, and Dianne Bourne.

Funds for one of us (C.C.W.) were provided by grants from the Council of Agriculture and Ministry of Economic Affairs, Taiwan, Republic of China. Additional support came from Commonwealth of Virginia Project 131052 and from Public Health Service Program Project grant DE-08972 from the National Institute of Dental Research.

\section{REFERENCES}

1. Cummins, C. S., and J. L. Johnson. 1971. Taxonomy of the clostridia: wall composition and DNA homologies in Clostridium butyricum and other butyric acid-producing clostridia. J. Gen. Microbiol. 67:33-46.

2. Holdeman, L. V., E. P. Cato, and W. E. C. Moore (ed.). 1977. Anaerobe laboratory manual, 4th ed. Virginia Polytechnic Institute and State University, Blacksburg.

3. Holdeman, L. V., and J. L. Johnson. 1982. Description of Bacteroides loescheii sp. nov. and emendation of the descriptions of Bacteroides melaninogenicus (Oliver and Wherry) Roy and Kelly 1939 and Bacteroides denticola Shah and Collins 1981. Int. J. Syst. Bacteriol. 23:399-409.

4. Holdeman, L. V., R. W. Kelley, and W. E. C. Moore. 1984. Genus I. Bacteroides Castellani and Chalmers 1919, 959, p. 604-631. In N. R. Krieg and J. G. Holt (ed.), Bergey's manual of systematic bacteriology, vol. 1. The Williams \& Wilkins Co., Baltimore.

5. Johnson, J. L. 1981. Genetic characterization, p. 450-472. In P. Gerhardt, R. G. E. Murray, R. N. Costilow, E. W. Nester, W. A. Wood, N. R. Krieg, and G. B. Phillips (ed.), Manual of methods for general microbiology. American Society for Microbiology, Washington, D.C.

6. Johnson, J. L. 1985. DNA reassociation and RNA hybridization of bacterial nucleic acids. Methods Microbiol. 18:33-74.

7. Moore, L. H., and W. E. C. Moore. 1991. Anaerobe laboratory manual, April 1991 update. Virginia Polytechnic Institute and State University, Blacksburg.
8. Moore, W. E. C., D. E. Hash, L. V. Holdeman, and E. P. Cato. 1980. Polyacrylamide slab gel electrophoresis of soluble proteins for studies of bacterial floras. Appl. Environ. Microbiol. 39:900-907.

9. Moore, W. E. C., L. V. Holdeman, E. P. Cato, R. M. Smibert, J. A. Burmeister, K. G. Palcanis, and R. R. Ranney. 1985. Comparative bacteriology of juvenile periodontitis. Infect. Immun. 48:507-519.

10. Parish, J. H. 1972. Principles and practice of experiments with nucleic acids. John Wiley \& Sons, Inc., New York.

11. Rigby, P. W. J., M. Dirkmann, C. Rhodes, and P. Berg. 1977. Labelling deoxyribonucleic acid to high specific activity in vitro by nick translation with DNA polymerase I. J. Mol. Biol. 113:237-251.

12. Saghai-Maroof, M. A., K. M. Soliman, J. A. Jorgensen, and R. W. Allard. 1984. Ribosomal DNA spacer-length polymorphisms in barley: Mendelian inheritance, chromosomal location, and population dynamics. Proc. Natl. Acad. Sci. USA 81:8014-8018.

13. Sasser, M. 1990. Identification of bacteria by gas chromatography of cellular fatty-acids. Microbial Identification, Inc., Newark, Del.

14. Selin, Y. M., B. Harich, and J. L. Johnson. 1983. Preparation of labeled nucleic acids (nick translation and iodination) for DNA homology and RNA hybridization experiments. Curr. Microbiol. 8:127-132.

15. Shah, H. N., and M. D. Collins. 1981. Bacteroides buccalis, sp. nov., Bacteroides denticola, sp. nov., and Bacteroides pentosaceus, sp. nov., new species of the genus Bacteroides from the oral cavity. Zentralbl. Bakteriol. Parasitenkd. Infektionskr. Hyg. Abt. 1 Orig. Reihe C 2:235-241.

16. Watanabe, J., Y. Benno, and T. Mitsuoka. 1983. Taxonomic study of Bacteroides oralis and related organisms and proposal of Bacteroides veroralis sp. nov. Int. J. Syst. Bacteriol. 33:5764.

17. Wetmur, J. G., and N. Davison. 1968. Kinetics of renaturation of DNA. J. Mol. Biol. 31:349-370.

18. Wilkins, T. D., and T. Thiel. 1973. A modified broth-disk method for testing the antibiotic susceptibility of anaerobic bacteria. Antimicrob. Agents Chemother. 3:350-356. 